\title{
UMA CONFRONTAÇÃO (AUSEINANDERSETZUNG) DE MARTIN HEIDEGGER COM EDMUND HUSSERL. EM BUSCA DE UMA CONCEPÇÃO HERMENÊUTICA DA FENOMENOLOGIA
}

\author{
Heidegger's confrontation with Edmund Husserl. \\ Searching for a hermeneutic conception of phenomenology
}

Bento da Silva Santos

Resumo: $\mathrm{O}$ artigo trata da confrontação crítico-positiva de Martin Heidegger com Edmund Husserl com base em dois momentos importantes de seu Denkweg ao longo da atividade docente nas Universidades de Freiburg e Marburg. O primeiro emerge no curso friburguense de 1919 intitulado "A ideia da filosofia e o problema da visão de mundo" (GA 56/57), onde Heidegger esboça sua concepção hermenêutica da fenomenologia com a introdução da expressão "intuição hermenêutica" no final da preleção acadêmica. O segundo momento selecionado da confrontação se dá no curso do semestre de inverno de 1923-1924 intitulado "Introdução à investigação fenomenológica" (GA 17), onde não somente critica diretamente as obras de seu mestre, mas também através da "destruição" tanto do "ponto de partida" quanto do "escopo" da fenomenologia, a saber: a apropriação husserliana de $R$. Descartes. Nesse sentido, trata-se de uma "polêmica contra Husserl disfarçada de crítica a Descartes". Do syn-philosophein inicial com Husserl ("A fenomenologia somos eu [Husserl] e Heidegger, de resto mais ninguém"), mesmo dentro de uma contínua tensão, Heidegger passa a uma

\footnotetext{
* Doutor em Filosofia pela PUCRJ - Professor Associado do Departamento de Filosofia da Universidade Federal do Espírito Santo - UFES. Coordenador do Programa de Pós-Graduação em Filosofia e bolsista de produtividade em pesquisa nível 02 do CNPq. Artigo recebido em 20/06/2017 e aprovado para publicação em 29/09/2017.
} 
ruptura cada vez mais radical até se consumar no parricídio completo ora nas preleções do semestre de verão de Marburg intituladas "Prolegômenos para a história do conceito de tempo" (GA20), ora na tentativa fracassada da elaboração a duas mãos do artigo "Fenomenologia" para a Encyclopaedia Britannica em 1927.

Palavras-chave: Fenomenologia. Intuição. Hermenêutica. Teorético. Reflexão. Conhecimento. Certeza.

Abstract: The article deals with the critical - positive confrontation of Martin Heidegger with Edmund Husserl, based on two important moments of Heidegger's Denkweg, throughout his teaching activity in the universities of Freiburg and Marburg. It is first in his 1919 Freiburg course, entitled "The idea of philosophy and the problem of world view" (GA 56/57), that Heidegger outlines his hermeneutic conception of phenomenology, with the introduction of the term "hermeneutic intuition", at the end of his academic lectures. The second moment of confrontation takes place in the winter semester of 1923-1924 and is entitled "Introduction to phenomenological research" (GA 17). There, Heidegger criticizes his master's works, both directly and through the "destruction" of the "starting point" and "scope" of phenomenology, namely Husserl's appropriation of R. Descartes. In this sense, it is a "polemic against Husserl disguised as criticism against Descartes." In a context of continuous tension, Heidegger moves away from the early syn-philosophein with Husserl - "Phenomenology is myself [Husserl] and Heidegger, nobody else". The philosopher makes an increasingly radical break until the parricide is consummated with both his Marburg summer lectures, entitled "Prolegomena to the history of the concept of time" (GA20) and the failed attempt to prepare, together with Husserl, the article "Phenomenology" for the Encyclopaedia Britannica in 1927

Key-words: Phenomenology. Intuition. Hermeneutics. Theoretical. Reflection. Knowledge. Certainty.

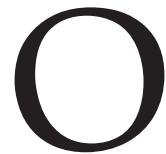
esboço da confrontação de Heidegger com Husserl é realizado aqui na perspectiva da figura principal da Auseinandersetzung, cujo objetivo não é resenhar a exatidão e a falsidade da hermenêutica tradicional ou de opor o "modo de ver" de um pensador a outro. $\mathrm{Na}$ verdade, é um face-à-face de pensamentos de tal modo que, com base na

\footnotetext{
${ }^{1}$ Minha opção fundamental aqui aceita as linhas básicas da crítica de Heidegger a Husserl, mas esta decisão não implica que a proposta de Heidegger seja filosoficamente melhor que a de Husserl. Simplesmente adoto o ponto de vista da interpretação heideggeriana da fenomenologia em sua "confrontação" filosófica com seu mestre Husserl. Trata-se, em última análise, da própria gestação da conceitualidade fenomenológica de Heidegger. Sobre a relação Heidegger-Husserl, cf. KISIEL, The Genesis of Heidegger's "Being and Time", 1995, p. 56-59.276-277.362-397.399-401; CRISTIN, Husserl-Heidegger: la fenomenologia in discussione, 1999, p. 11-129; GANDER, Phänomenologie im Übergang. Zu Heideggers Auseinandersetzung mit Husserl, 2004, p. 294-306; RESE (Hrsg), Heidegger und Husserl im Vergleich, 2010; GANDER, Phänomenologie der Lebenswelt: Husserl und Heidegger, ${ }^{22013, ~ p . ~ 137-158 . ~}$
} 
confrontação crítica de posições recíprocas, possam pensar mais originariamente a verdade de seu próprio pensamento. Segundo o modo de apropriação heideggeriano de proceder em relação à tradição filosófica, pensar com Husserl implica ao mesmo tempo estabelecer uma autêntica crítica aos pressupostos da fenomenologia transcendental e, nesse sentido, não se trata mais do simples syn-philosophein com seu mestre quando Heidegger em 1919 se torna docente assistente de Husserl na Universidade de Freiburg. A única maneira de apreciar autenticamente um pensador como, por exemplo, foi o caso emblemático com seu mestre Husserl, é justamente entrar em confrontação com ele: para compreendê-lo, é preciso ouvi-lo, e para ouvi-lo, é necessário oferecer à sua filosofia "a possibilidade de dizer o que ela quis dizer", mas não disse explicitamente. Nesse sentido, pensar como filósofo com outro pensador significa "arrancar" dele o que não disse, mas "queria dizer", para pensar um pensamento que diz o que os outros não puderam ou não souberam dizer. Pensar é, portanto, abrir um caminho, abrir seu pensamento através de outros pensamentos. Daí provém a metáfora do Denkweg para expressar o desdobramento do pensamento de Heidegger no século XX. Assim compreende-se a estratégia heideggeriana de apropriação das obras filosóficas: a necessidade de familiarizar-se com a paixão oculta na obra e a obrigação de dizer o que há de tácito nela. Portanto, a interpretação que força o texto se justificaria a partir de uma coerção que surge supostamente do texto a ser interpretado $^{2}$. É assim que justifico minha posição em relação à confrontação de Heidegger com Husserl no período de sua docência em Freiburg (19191923) e Marburg (1923-1928), mesmo admitindo a complexidade desse confronto na literatura recente ${ }^{3}$. $\mathrm{O}$ artigo, portanto, se articula em três partes: primeiramente, apresento brevemente a relação conflituosa de proximidade e distância entre Heidegger e Husserl com base em testemunhos e confissões epistolares. Em seguida, examino o conteúdo de dois cursos de Heidegger ministrados, respectivamente, nas Universidades de Freiburg (semestre do pós-guerra de 1919) e Marburg (semestre de inverno de 1923-1924). Nessas preleções acadêmicas Heidegger se confronta com seu mestre, ora no clima tenso do syn-philosophein (Die Idee der Philosophie und das Weltanschauungsproblem, GA [= Gesamtausgabe] 56/57), ora na flagrante ruptura com o ideal husserliano de uma filosofia como ciência rigorosa, isenta de pressupostos, transparente e neutra (Einführung in die phänomenologische Forschung, GA 17).

\footnotetext{
${ }^{2}$ HEIDEGGER, Kant und das Problem der Metaphysik (1929) (GA 3), ${ }^{5} 1991$, XVII.

${ }^{3}$ Não é meu objetivo examinar aqui a justeza ou não das interpretações heideggerianas, mas simplesmente de esboçar a gestação de seu Denkweeg durante sua atividade docente. A propósito, cf. BRAVER, Analyzing Heidegger: a history of analytic reactions to Heidegger, 2015, p. 235-255.
} 


\section{Com os "olhos de Husserl" em direção ao ponto cego do mestre}

A julgar pelo Denkweg de Heidegger até o último curso ministrado na Universidade de Freiburg no semestre de verão de 1923, Ontologia (Hermenêutica da facticidade) (GA 63), onde testemunha que Husserl "abriu-lhe os olhos", ou seja, formou sua visão filosófica, a relação de Heidegger com seu mestre foi simultaneamente de proximidade e distanciamento crítico: “O companheiro em minha busca foi o jovem Lutero e o modelo Aristóteles, a quem Lutero odiava. Os impulsos me foram dados por Kierkegaard e foi Husserl quem me abriu os olhos" ${ }^{4}$. Se o implante do olhar fenomenológico evidencia a proximidade desde os inícios de sua formação acadêmica, essa mesma abertura do olhar descobre paulatinamente, virado contra Husserl, o ponto cego desse último que será explicitado no lugar exato do parricídio heideggeriano durante o curso do semestre de verão de 1925 intitulado Prolegômenos para uma história do conceito de tempo: Husserl omitiu a questão do "ser" do "ente intencional" (a existência humana e seus comportamentos) e ao mesmo tampo ignorou a "questão do ser em geral como tal" (dando por óbvio a visão tradicional segundo a qual "ser" significa "presença" [Vorhandensein] e crendo que o maximamente presente - a essência e a vivência - é o que fundamenta tudo aquilo cuja presença não seja tão clara nem completa, etc. $)^{5}$. De um lado, a familiaridade com a fenomenologia de Husserl se verifica antes mesmo da chegada desse último em Freiburg em 1 de abril de 1916 quando substitui o neokantiano Heinrich Rickert, que partira para Heidelberg com o objetivo de assumir a cátedra de W. Windelband, seu mestre. Através de uma carta de 3 de julho de 1914 endereçada a Rickert pelo próprio Heidegger sabemos que esse último já tinha entrado em contado epistolar com Husserl, ao menos desde o mês de julho de $1914^{6}$. Nela Heidegger comunica a Rickert acerca das respostas que recebeu de Husserl, entre as quais se encontra a informação de que supostamente Husserl teria decidido escrever um terceiro volume completo das Investigações lógicas. Ora, segundo carta endereçada ao seu protetor e amigo pessoal Engelbert Krebs, aos 19 de julho de 1914, Heidegger declina a intenção de sacrificar suas férias para consagrar-se à leitura da fenomenologia husserliana e, desse modo, evitar interpretações parciais. A intenção de sacrificar suas férias para revisar a proposta fenomenológica de Husserl terá sido motivada pela resposta desse último a Heidegger na mencionada correspondência de 1914? Nunca saberemos com certeza, uma vez que as

\footnotetext{
${ }^{4}$ HEIDEGGER, Ontologie. (Hermeneutik der Faktizität) (GA 63), 2012a, p. 11.

${ }^{5}$ HEIDEGGER, Prolegomena zur Geschichte des Zeitbegriffes [SS 1925] (GA 20), 1975, p. 157, $179,178$.

${ }^{6}$ Carta citada em DENKER, Heideggers Lebens- und Denkweg 1909-1919, in DENKER, A.; GANDER, H.-H.\& ZABOROWSKI, H. (Hrsg.), Heidegger und die Anfänge seines Denkens, 2004, p. 119, nota 117.
} 
cartas entre Heidegger e Husserl não foram conservadas 7 . De outro lado, é no interior dessas aproximações de Heidegger com a fenomenologia de Husserl entre 1911 e 1916 que descortinamos distanciamentos críticos que culminaram definitivamente em 1927 com o fracasso da elaboração a duas mãos do artigo "Fenomenologia" para a Encyclopaedia Britannica: na carta de 22 de outubro de 1927 endereçado ao "querido amigo paternal" [isto é, a Husserl], Heidegger, entre outros pontos, rejeita que a "consciência" (ou o Eu reflexivo) seja o tema da fenomenologia porque julga que, assim procedendo, deixa-se escapar a explicitação adequada do "ser" da "vida humana" ${ }^{8}$. A fonte mesma de toda significatividade, e não somente filosófica, jaz na situação fática, realizada e vivenciada como própria por um si no mundo". Daí o esforço de Heidegger que conduzirá ao coração de sua fenomenologia hermenêutica: o "retorno às coisas mesmas" consiste em "realizar em profundidade a própria situação fática de maneira sempre mais originária e, na atuação, prepará-la para a genuidade"10.

Mas, dez anos antes da colaboração fracassada mencionada há pouco, Heidegger já tinha divergências expressas com o pensamento de Husserl, como podemos constatar em carta dirigida a Elfride Petri aos 20 de maio de 1917 e com quem casou civilmente aos 20 de março do mesmo ano e, no dia seguinte, segundo o ritual católico na capela universitária:

"Não posso aceitar a fen[omenologia] de Husserl como coisa definitiva (Endgültigkeit), ainda que se aproxime da filosofia, porque é demasiado limitada e sem vida, tanto em seu ponto de partida (im Ansatz) como em seu propósito (im Ziel), e porque uma tal maneira de abordar as coisas não pode ser absolutizada. A vida é muito rica e muito grande " por essa razão importa, para as relatividades que tentam apreender seu sentido (o de Absoluto) sob forma de sistemas filosóficos, de descobrir o caminho libertador para uma figuração absoluta da relatividade" ${ }^{11}$.

Esta rejeição da fenomenologia husserliana como algo definitivo constituirá a complicada relação entre mestre e discípulo, uma relação, se assim podemos dizer, de "amor" e "ódio" na suposta amizade anímica do syn-philosophein. Esta relação de "amor-ódio" de Heidegger para com Husserl transparece inequivocamente em carta endereçada a Karl Jaspers aos 14 de julho de 1923:

"Você sabe que Husserl foi proposto para Berlin; comporta-se pior que um Privatdozent que mudaria sua felicidade por um posto de titular. O que

\footnotetext{
${ }^{7}$ Cf. XOLOCOTZI \& TAMAYO, Los demonios de Heidegger. Eros y manía en el maestro de la Selva Negra, 2012, p. 63.

${ }^{8}$ Cf. ESCUDERO PÉREZ, Husserl y Heidegger en 1927, 2015, p. 68.

9 ARRIEN, L'inquiétude de la pensée. L'herméneutique de la vie du jeune Heidegger (1919-1923), 2014, p. 214.

${ }^{10}$ HEIDEGGER, Phänomenologie der Anschauung und des Ausdrucks (GA 59), 1993b, p. 30.

${ }^{11}$ Carta do domingo da Ascensão de 1917, in HEIDEGGER, Alma mia! Cartas a su mujer Elfride 1915-1970, 2008, p. 74-75.
} 
ocorre está envolvido em penumbras: antes de tudo vê-se que o praeceptor Germaniae - Husserl está totalmente sem juízo [...] - vai daqui para lá dizendo trivialidades, o que dá muita pena. Vive de sua missão de "fundador da fenomenologia", ninguém sabe o que é - quem está aqui um semestre sabe o que acontece..."12.

Se essas cartas já deixam entrever a relação complexa e certamente tensa entre mestre e aluno, do ponto de vista do relacionamento de Husserl com Heidegger, antes de 1927, onde aparece a auto decepção husserliana acerca do desenvolvimento em direção a um pensamento autônomo do discípulo, predomina, porém, uma ampla promoção acadêmica do próprio Heidegger. É assim que, por exemplo, aos 7 de janeiro de 1919 Husserl envia um escrito ao Ministério de Cultura solicitando um lugar de assistente para Heidegger em razão de "sua valiosa força científica", que não poderia ser paralisada e perdida para a Universidade. É desse modo que, com ajuda de Husserl, Heidegger conseguiu o lugar de assistente (Privatdozent) na Universidade de Freiburg precisamente no dia 21 de janeiro de 1919 e, dessa maneira, acontece a virada institucional de Heidegger: da teologia para a filosofia.Nessa mesma época, em carta dirigida a Paul Natorp em fevereiro de 1920, Husserl via em Heidegger um autêntico discípulo: "Nos últimos dois anos ele [Heidegger] foi para mim o colaborador mais valioso; tenho dele como docente e como pensador as melhores impressões e ponho nele toda a minha esperança..." "13. Em outra carta a Natorp em 1922, afirma Husserl sobre Heidegger: "Suas capacidades receptivas são mínimas, é o mais contrário a um acomodatício. Uma personalidade totalmente original, girando em torno de si mesmo e buscando a maneira fundada de modo próprio e criando dedicadamente. Sua forma de ver, de trabalhar fenomenologicamente e o campo mesmo de seus interesses - nada disso é tomado simplesmente de mim, mas [está] arraigado em sua própria originalidade [...]"14. Com base nessas afirmações, Husserl certamente dizia syn-philosophein e pensava como sua "escola", desejando ter alguém ao seu lado para prosseguir suas investigações, alguém que a pensasse como ele, que visse o mundo com seus próprios olhos ${ }^{15}$. A partir de seu primeiro curso no semestre do pós-guerra em 1919 intitulado $A$ ideia da filosofia e o problema da visão de mundo (GA 56/57), Heidegger tomará o "episódio" Husserl como "preceito regulador" e prático, mas em um syn-philosophein como confrontação recíproca de posições, livres e diversas ${ }^{16}$. A proximidade com o Mestre nunca será empecilho para Heidegger lutar com aquele que lhe "abriu os olhos". No ano de 1920, por exemplo, Heidegger reitera suas diferenças com Husserl em outra carta à sua esposa Elfride:

\footnotetext{
${ }^{12}$ HEIDEGGER \& JASPERS, Correspondencia (1920-1963), 2003, p. 35.

${ }^{13}$ Apud XOLOCOTZI \& TAMAYO, 2012, p. 69.

${ }^{14}$ Apud XOLOCOTZI \& TAMAYO, 2012, p. 72.

${ }^{15}$ Cf. CAPUTO, Pensiero e affettività: Heidegger e le Stimmungen (1889-1928), 2001, p. 99-100.

${ }^{16}$ Cf. XOLOCOTZI \& TAMAYO, 2012, p. 67.
} 
“Encaminhamo-nos para uma posse verdadeira, simples e elementar da vida, para a criação de um novo estilo que não segue programas, mas os impulsos que crescem em nossa intimidade. Isso mesmo é o que me separa abismalmente de Husserl..."17.

A relação pessoal e filosófica entre Husserl e Heidegger é, portanto, assaz complexa, sobretudo se partirmos da compreensão mútua que tiveram ambos com base em seus respectivos epistolários. Desde seus inícios Heidegger reconheceu suas diferenças com Husserl, mas este último só tardiamente percebeu tais diferenças e a consequente incompatibilidade com seu modo de compreender a fenomenologia. Com base nesse epistolário, sabemos que o distanciamento entre Heidegger e Husserl se deteriorou por motivos acadêmicos. Em carta de 19 de novembro de 1927 endereçada a Roman Ingarden, Husserl se expressa bem diferente da carta trocada com Natorp em 1922: "Lamentavelmente eu não determinei sua [Heidegger] formação filosófica, obviamente já possuía um caráter próprio quando estudou meus escritos". Após já ter lido criticamente Ser e Tempo de Heidegger bem como Max Scheler em vista de conferências sobre "fenomenologia e antropologia" (Sociedade Kant) em Berlin, Halle e Frankfurt, Husserl confessará a Alexander Pfänder em 1931 sua atitude em relação a Heidegger: "Cheguei à triste conclusão de que filosoficamente não tenho nada a ver com esta "profundidade" heideggeriana, nem com esta genial não-cientificidade; de que a crítica pública e secreta de Heidegger se baseia em um crasso mal-entendido; de que ele está em vias de formação de uma filosofia sistemática e eu sempre consagrei minha vida a fazer impossível para sempre esse tipo de filosofia"18.

Em função dessa complexidade e da impossibilidade de tratar todos os pormenores da relação Heidegger-Husserl, selecionei dois momentos significativos do esboço da fenomenologia hermenêutica nas atividades docentes de Heidegger em contraposição com a fenomenologia teorética de Husser ${ }^{19}$. No contexto das preleções ministradas em Freiburg (19191923) quando Heidegger entende a filosofia como ciência originária da

\footnotetext{
${ }^{17}$ HEIDEGGER, 2008, p. 117-118.

${ }^{18}$ Apud XOLOCOTZI \& TAMAYO, 2012, p. 72-73.

${ }^{19}$ Para uma abordagem mais extensa, ver KOVACS, Philosophy as Primordial Science in Heidegger's Courses of 1919, 1994, p. 91-107; ADRIAN ESCUDERO, Heidegger y la genealagía de la pregunta por el ser. Una articulación temática y metodológica de su obra temprana, 2010, p. 426-525: "Fenomenología reflexiva versus fenomenología hermenéutica"; IDEM, Guía de lectura de Ser y Tiempo de Martin Heidegger, 2016, p. 133-144; Cf. também as seguintes sínteses: CAMPBELL, The Early Heidegger's Philosophy of Life. Facticity, Being, and Language, 2012, p. 23-32 (sobre GA 56/57), p. 141-161 (sobre GA 17); FISCHER, Religiöse Erfahrung in der Phänomenologie des frühen Heidegger, 2013, p. 135-177; WESTERLUND, Phenomenology as Understanding of Origin. Remarks on Heidegger's First Critique of Husserl, in RESE, F. (Hrsg.), Heidegger und Husserl im Vergleich, 2010, 34-56; PERRIN, Entendre la métaphysique. Les significations de la pensée de Descartes dans l'oeuvre de Heidegger, 2013, p. 100-126.
} 
vida, o primeiro acontece durante o curso do semestre emergencial por motivos da guerra de 1919 intitulado A ideia da filosofia e o problema da visão de mundo (GA 56/57). Nesse curso, de um lado, há uma crítica inicial dos postulados teoréticos da fenomenologia husserliana e ao mesmo tempo, de outro lado, são lançados os fundamentos da hermenêutica fenomenológica com base no primado do pré-teorético. Dentro do período de docência de Heidegger em Marburg (1923-1928), o segundo diz respeito ao desenvolvimento da fenomenologia hermenêutica no curso do semestre de inverno de 1923-1924 intitulado Introdução à investigação fenomenológica (GA 17). Nesse curso já aparece um distanciamento expressivo em relação à fenomenologia de Husserl não só com a crítica às obras do mestre (Logische Untersuchungen e Ideen I), mas também através da "destruição" tanto ao "ponto de partida" (im Ansatz) quando ao "escopo" (im Ziel) da fenomenologia de Husserl: a apropriação husserliana de René Descartes. Deste último Husserl teria retomado duas ideias norteadoras: "a ideia da filosofia enquanto ciência autofundada fundadora última e unificadora da totalidade das ciências, e a ideia da subjetividade transcendental, solo de todo saber dotado de verdadeira cientificidade" ${ }^{20}$. Portanto, nesse curso marburguense Heidegger crítica a insistência do cartesianismo de Husserl sobre a certeza e a validade como verdadeiro escopo da reflexão filosófica e reitera que a imposição desse modelo matemático é anti-fenomenológico.

\section{A fenomenologia como "ciência originária pré- teorética" (vortheoretischen Urwissenschaft)}

No ano em que Heidegger rompe oficialmente com a Igreja católica, isto é, com o "sistema do catolicismo", como ele mesmo afirma em uma carta ao cônego Engelbert Krebs de janeiro de 09 de janeiro de 191921, mas já anunciada a Elfride desde 4 de setembro de $1918^{22}$, outra ruptura se descortina com seu primeiro curso de pós-guerra ministrado na Universidade de Frieburg na qualidade de Privatdozent: o Kriegsnotsemester (semestre emergencial por motivos da guerra de 1919) ${ }^{23}$ de Heidegger, em um apreender constante na companhia de Husserl, traz a marca de um parricídio. Nas preleções desse período Heidegger realiza um exame crítico da filosofia neokantiana dos

\footnotetext{
${ }^{20}$ PERRIN, 2013, p. 91.

${ }^{21}$ HEIDEGGER, Briefe Martin Heideggers an Engelbert Krebs (1914-1919), 2004, p. 67-68.

22 “Toda minha indecisão anterior, minha hipocrisia e casuística nada mais são do que a consequência forçada de minha educação hipercatólica, com a qual - por outro lado - sempre me propus romper, embora sem contar com os meios para fazê-lo [...] a questão se enraíza na íntima ausência de liberdade do sistema católico, em seu despotismo da consciência que se apresenta como piedade", HEIDEGGER, 2008, p. 94-95.

${ }^{23}$ HEIDEGGER, Die Idee der Philosophie und das Weltanschauungsproblem (Kriegsnotsemester1919), in Zur Bestimmung der Philosophie (GA 56/57), 1999a, p. 1-117.
} 
valores, da qual um dos principais representantes foi seu próprio Doktorvater Heinrich Rickert que aceitou em 1915 o trabalho de Heidegger ( $A$ doutrina das categorias e do significado em Duns Scoto) ${ }^{24}$ como a Tese de Habilitação para a Faculdade de Filosofia. No curso "A ideia da filosofia e o problema da visão de mundo" acontece esse "aprender combatendo" na companhia de Husserl, e aí Heidegger volta-se assim para o intuicionismo husserliano no sentido de ser a única maneira possível de salvar a ideia da filosofia como "ciência originária" (Urwissenschaft). Na medida em que reflete a escolha a favor ou contra a fenomenologia, esse esquema de "aprender combatendo" transparece como escolha dramática entre a vida e a morte: "Encontramo-nos ante a encruzilhada metodológica que decide sobre a vida ou a morte da filosofia em geral, diante de um abismo: ou nos precipitamos no nada, isto é, no reino da objetividade absoluta (der absoluten Sachlichkeit = absoluta coisidade), ou conseguimos saltar para um outro mundo, ou mais exatamente: no mundo como tal"25. A natureza desse "salto" diz respeito certamente ao problema da doação ou, mais precisamente, da descoberta do que Heidegger chama de "alguma coisa originária" (Ur-Etwas) ("'Há [Gibt es]...?' Alguma coisa já se dá [gibt es etwas])"26. Tal "mundo" não é mais objeto de visão! Esse novo acesso ao "mundo" de que fala Heidegger é a "vivência da pergunta", mas sem que haja evidentemente um liame essencial entre mundo e pergunta à semelhança da correlação da visão na "visão de mundo". É justamente a "vivência da pergunta" que possibilita evitar toda "posição". Mas concretamente é a "vida", compreendida como fenômeno fundamental, que oferece o âmbito para descobrir esse Ur-Etwas. É na vida vivida [Erlebnis] que encontramos o espaço emergencial do "Há" (es gibt); é a partir daqui que se prepara a investigação em busca da origem ${ }^{27}$. Portanto, desde o início de sua docência em Freiburg, Heidegger coloca o problema fenomenológico dessa "alguma coisa originária" na vida pré-teórica, ou seja, na experiência fática da vida que está absorvida em nexos de significatividade. Com base na apropriação fecunda da fenomenologia no sentido de sua concepção hermenêutica, Heidegger a compreenderá doravante como "ciência originária pré-teórica" (vortheoretischen Urwissenschaft)" como "ciência originária da vida

\footnotetext{
${ }^{24}$ HEIDEGGER, Die Kategorien- und Bedeutungslehre des Duns Scotus, 1916. Publicação retomada in: Frühe Schriften (1912-1916) (GA 1), 1978, p. 189-411.

${ }^{25}$ HEIDEGGER,1999a, 63.

${ }^{26}$ HEIDEGGER, 1999a, p. 63-70: “\$13. A vivência da pergunta: Há alguma coisa?" (Das Frageerlebnis: Gibt es etwas?)". O sujeito da proposição predicativa submetido à pergunta é eclipsado pelas reticências de suspensão e, portanto, substituído pelo "es" impessoal. Este caráter de impessoalidade "remete para um preenchimento, preenchimento possível para tudo o que pode aparecer, o que significam os pontos de suspensão". A "fusão semântica" do verbo "Gibt" com o impessoal "es" - "es gibt" -, "torna impossível toda relação de dependência e de independência formal entre os dois, porque uma relação deste tipo restabeleceria imediatamente as aporias da deformação predicativa": O "Das ist" de "Was ist das?" pode opor-se radicalmente ao "Gibt es...?". Cf. QUESNE, Les Recherches philosophiques du jeune Heidegger, 2003, p. 38-40.

${ }^{27}$ Cf. ARRIEN, 2014, p. 68-69.
} 
em si (Urprungswissenschaft vom Leben an sich)" ${ }^{28}$. Trata-se agora de buscar um método fenomenológico radicalmente novo para abordar a vida experiencial. Uma vez que esta vida vivida não é um objeto, não deveríamos inferir que ela deveria ser, portanto, um sujeito (concebido tradicionalmente como epistemológico ou psicológico): "objetivação $e$ subjetivação" são as duas deformações teóricas da vida ${ }^{29}$. Consequentemente, Heidegger luta nesses anos de docência contra a "absolutização injustificada do teorético" ${ }^{30}$ ou também designado por ele mesmo como "reino geral do teorético". Ainda que vise de modo geral o neokantismo, Husserl é igualmente um destinatário possível dessa crítica. Será com base na dimensão da ciência originária que Heidegger ultrapassará ao mesmo tempo, no Kriegsnotsemester, ora o sentido clássico de ciência através da "vivência da pergunta", ora, de maneira imanente, o conceito de "mundo" na "visão de mundo". Essas duas tentativas heideggerianas estão associadas à sua ideia de filosofia em 1919.

Concretamente, no que diz respeito à sua atitude crítica fundamental para com Husserl, Heidegger passa do debate com o neokantismo na primeira parte do curso $A$ ideia da filosofia e o problema da visão de mundo (GA 56/57) para, mediante uma "experiência de pensamento" ("es gibt", §§ 12-13 do curso $^{31}$, "converter-se" à fenomenologia husserliana na segunda parte ${ }^{32}$. A transformação de fenomenologia em hermenêutica realiza-se a partir da vida fática, e Heidegger inicia justamente sua fenomenologia hermenêutica na reinterpretação dada ao "princípio dos princípios"33 de Husserl no §20 (desse mesmo curso de 1919) intitulado "A abertura fenomenológica da esfera das vivências" ${ }^{34}$. Husserl o formula da seguinte maneira: "tudo o que se dá originariamente na 'intuição' [...] deve ser tomado simplesmente tal como ele se dá". Heidegger adapta o princípio ao seu próprio questionamento no que diz respeito à relação entre intuição e expressão (Ausdruck). Quanto a essas duas noções, trata-se aqui de dois aspectos inseparáveis de uma mesma questão ${ }^{35}$. Heidegger afirma que o "princípio" é de natureza não teorética, uma vez que Husserl fala "de algo que precede a todos os princípios e que 'nos salvaguarda dos erros de qualquer teoria imaginável'". Portanto, longe de ser uma proposição teorética, o "princípio dos princípios" da

\footnotetext{
28 HEIDEGGER, Grundprobleme der Phänomenologie (Wintersemester 1919/20) (GA 58), 1993a, (2010), p. 1.79.

${ }^{29}$ HEIDEGGER, 1993a, p. 145-146.236. Cf. também ZAHAVI, Comment examiner la subjectivité?

À propos de la réflexion: Natorp e Hiedegger, 2011, p. 103-104.

${ }^{30}$ HEIDEGGER, 1999a, p. 87.

${ }^{31}$ HEIDEGGER, 1999a, p. 59-70.

32 GREISCH, L'Arbre de vie et l'arbre du savoir. Les racines phénoménologiques de l'herméneutique heideggerienne (1919-1923), 2000, p. 39: "Heidegger se converteu à fenomenologia husserliana". ${ }^{33}$ HUSSERL, Ideias I, § 24, 69. (trad. bras.: Ideias para uma fenomenologia pura e para uma filosofia fenomenológica. Livro Primeiro, 2006). Nas citações, menciono o parágrafo de Ideias I seguido imediatamente da página da tradução brasileira.

${ }^{34}$ HEIDEGGER, 1999a, p. 109-117.

${ }^{35}$ Cf. ARRIEN, 2014, p. 101-104.
} 
fenomenologia significa, na leitura heideggeriana, a "intenção originária da vida verdadeira em geral, a atitude originária da vivência e da vida como tais, a absoluta simpatia com a vida que é idêntica com o viver mesmo". $\mathrm{O}$ "princípio" expressa uma "atitude fundamental" que se torna absoluta à medida que vivemos nela mesma - "e isto, nenhum sistema conceitual concebido até hoje o realizou, mas somente a vida fenomenológica em seu crescimento de si sempre maior"36. Com base nesse "hábito originário", a vida fenomenológica não poderá ser aprisionada na "gaiola" de uma consciência pura, como é o caso ainda da abordagem teorética de Husserl. Daí porque, na esteira de Descartes e de Kant, Husserl utiliza o esquema sujeito-objeto segundo uma inflexão epistemológica. Mas esta reflexão teorética é incapaz de compreender e clarificar estruturalmente a "vivência da vida vivida (Erlebendes Erlebens) que conduz a si mesma". Ora, esta vivência que se apropria da experiência vivida é justamente a "intuição hermenêutica (hermeneutische Intuition)" ${ }^{37}$. Além da presença inequívoca de Husserl, por trás da junção desses dois termos é latente também a interiorização das "preciosas intuições" de W. Dilthey, que permitiram a Heidegger "assegurar à dimensão do pré-teórico uma segura intelectualidade que liberta a sua tentativa de todo fácil irracionalismo vitalístico"38. $\mathrm{Na}$ fórmula "intuição hermenêutica" descortina-se a "síntese viva entre a abordagem hermenêutica de Dilthey e a fenomenologia (como filosofia) rigorosa de Husserl" ${ }^{\prime 39}$. Em debate também com a concepção husserliana da intuição fenomenológica, segundo a qual no "ver fenomenológico" a esfera da vivência é concebida como algo dado (objeto) que deve ser descrito (conhecimento), Heidegger entende a intuição hermenêutica fora dessa linguagem teorética para integrá-la a uma concepção segundo a qual a vida, do ponto de vista fenomenológico, deve ser aceita tanto em sua heterogeneidade quanto em sua indissolúvel pluralidade. Assim procedendo em relação ao conceito "vida", Heidegger exclui a ideia de uma totalidade possivelmente harmoniosa. Na verdade esse campo originário de experiência veicula significatividades que apontam para uma compreensão elementar. Considerando que o conhecimento fenomenológico é constituído "por um conjunto de momentos de apreensão e de expressão", "o primeiro estágio da investigação fenomenológica é o compreender" 40 . Portanto, à luz deste compreender, não se trata mais de uma correlação entre intuição e vivências no sentido husserliano (onde se identifica "intuição" fenomenológica com a intuição de objetos), mas de uma correlação entre compreender e vida. Só assim esta última, subtraindo-se de toda determinação objetiva ou coisal, poderá ser explicitada em seu caráter situado: “a vida como correlato de

\footnotetext{
${ }^{36}$ HEIDEGGER, 1999a, p. 110.

${ }^{37}$ HEIDEGGER, 1999a, p. 117.

${ }^{38}$ JACOBSSON, Heidegger e Dilthey. Vita, morte e Storia, 2010, p. 98.

${ }^{39}$ SCHMIDT, La vie comme défi phénoménologique. La pensée du jeune Heidegger comme critique de la science rigoureuse, 2011, p. 123.

${ }^{40}$ HEIDEGGER, 1993a, p. 237-238.
} 
um compreender originário não possui nem um caráter de objeto, nem um estado de coisas" ${ }^{\prime 4}$. Examinando a vida fática sob o aspecto da ciência da origem, Heidegger afirma que "a vida fala a si mesma em sua própria língua. Isso atinge até suas estruturas fundamentais" ${ }^{\prime 2}$. Nesta afirmação reside o nexo entre os três aspectos da vida fática quando é apreendida sem teoria: autossuficiência, expressão e significatividade (Bedeutsamkeit). O caráter de significatividade exibido pela vida mesma não diz respeito à concepção de vida que "flui de forma surda", mas, sim, ao fato de que é compreensível.

A intuição hermenêutica é o "comportamento frente a alguma coisa" (Verhalten zu etwas) familiarizado consigo mesmo, de modo que o algo (Etwas) abordado não pode ser compreendido em sentido tradicional como objeto (Objekt) ou como algo que se encontra contraposto (Gegenstand), e também nem como um algo familiarizado através da "teorização mais sublime" 43 . Uma vez que "tudo o que pode ser vivenciável em geral é um possível algo (mögliches Etwas), independentemente de seu genuíno caráter mundano [seja de tipo estético, religioso ou social]", o sentido desse "algo (Etwas)" aponta para o "vivenciável em geral". Ora, a indiferença que está em geral implicada no "algo" não se identifica "com a privação de vida ou com o grau máximo desta privação" ${ }^{44}$. Esse "algo", entendido como "o vivenciável em geral" significa um afastamento radical do teorético para deixar florescer um "momento essencial da vida em si e para si" ${ }^{45}$. Na "intuição hermenêutica" habita esse "algo" na medida em que é "indício da mais alta potencialidade da vida". Se "a fenomenologia deve ser ciência da vida em si, não de tal ou qual fragmento de um mundo da vida, mas da vida em si" ${ }^{\prime 4}$, compreende-se dessa maneira que tal ciência da vida em si não se

\footnotetext{
${ }^{41}$ HEIDEGGER, 1993a, p. 237.

${ }^{42}$ HEIDEGGER, 1993a, p. 231-232.

${ }^{43}$ HEIDEGGER, 1999a, p. 112.115.

${ }^{44}$ A autossuficiência da vida fática se caracteriza justamente por essa indiferença, que é entendida assim por Heidegger no curso friburguense do semestre de inverno de 1920/1921 (Introdução à fenomenologia da religião): "A experiência fática da vida manifesta uma indiferença em relação ao modo de experimentar [...] Esta indiferença funda assim a autossuficiência (Selbstgenügsamkeit) da experiência fática da vida. Esta se expande sobre tudo: em sua autossuficiência, ela decide também as coisas supremas" [...] "A experiência fática da vida é "preocupação autossuficiente da significatividade', em conformidade com uma posição particular, decadente, indiferente à sua referência": HEIDEGGER, Einleitung in die Phänomenologie der Religion, in Phänomenologie des religiösen Lebens (Wintersemester 1920/1921) (GA 60), 1995 ('2011), p. 12.16. ${ }^{45}$ HEIDEGGER, 1999a, p. 115-116.

${ }^{46}$ HEIDEGGER, 1993a, p. 79.27: “Que significa que a 'vida em si' não está dada de antemão para a problemática fenomenológica, mas que deve ser dada mediante um processo motivado de algum modo a partir da vida mesma?" [...] "A existência sem significatividade não tem absolutamente nenhuma possibilidade de motivação" (217). Nas problemáticas da doação distinguidas nessa preleção (GA 58, 224: os Neokantianos e Husserl), Heidegger explicita sua própria concepção: “É preciso distinguir: a) 'ser dado' no sentido de colocado por mim, isto é, o caso em que me 'dou' algo. b) 'Dado' no sentido do que é dado previamente (Vorgabe) a mim (do exterior)". Cf. o exame detalhado de QUESNE, 2003, p. 91-104. Ora "chegar a esta doação [isto é, à vida em si] que se indica na vida, é saber que a vida, do ponto de
} 
confunde, portanto, com os mundos estético, religioso, social, etc. Daí a necessidade de pensar a vida enquanto ainda-não (Noch-nicht), isto é, da vida que ainda não irrompeu na produção de um mundo particular. Trata-se do "essencialmente pré-mundano" (wesenhaft Vorweltliche), que não deve ser concebido teoreticamente ${ }^{47}$. Nesse "pré-mundano" a imanência do mundo certamente não é omitida; o "algo pré-mundano" de que fala Heidegger no curso $A$ ideia da filosofia e problema da visão de mundo, portanto, está associado fundamentalmente ao "caráter de evento (Ereignischarakter) das vivências (Erlebnisse) como tais" 48 . Nesse experienciar "algo pré-mundano" se exibe a "atitude fundamental do vivo ir-com (des lebendigen Mitgehens) o autêntico sentido da vida, do integrar-se a ele compreensivamente" ${ }^{\prime \prime}$. O que quer dizer esse "acompanhar" o verdadeiro sentido da vida de forma compreensiva? No curso friburguense do semestre de inverno de 1919/1920 (Problemas fundamentais da fenomenologia), Heidegger estabelece que a atitude verdadeiramente filosófica se identifica com o erōs filosófico: O erōs implica, enquanto "exercício filosófico mesmo" e [...] não só como fundamento motivador da filosofia, um "entregar-se às tendências últimas da vida e um retroceder aos seus motivos últimos". A tarefa da intuição hermenêutica só pode ser realizada a partir do "aprofundamento do si-mesmo em sua originariedade" ${ }^{\prime 50}$. É, portanto, justamente em torno desse "si-mesmo" (Selbst) que reside o ponto de partida da filosofia para Heidegger nos anos de 1920: “O que está em questão na filosofia é de algum modo esse si-mesmo [...] Trata-se, em suma, de tomar o si-mesmo concreto como ponto de partida dos problemas e de levá-lo a tornar-se um "dado" no nível fundamental próprio à interpretação fenomenológica, a saber, à interpretação referida à experiência fática da vida como tal" ${ }^{\prime 51}$.

No contexto da transformação hermenêutica da fenomenologia esboçada em A ideia da filosofia e o problema da visão de mundo, Heidegger afirma que a mesma, em sua expressão linguístico-semântica de cada momento como "significatividade", não deve ser pensada "em termos teoréticos ou objetivos, mas há de ser originariamente vivida (ursprünglicher lebend)"52; por essa razão, continua Heidegger, "a universalidade do significados verbais significa primariamente alguma coisa de originário: mundanidade

vista metódico, é o pré-dado, mas que precisamente, enquanto pré-dado, ela não é a doação" [...] "O que, partindo do pré-dado, chega à doação, é a compreensão": QUESNE, 2003, p. 184-185. Portanto, a doação mais originária, longe de ser diretamente dada, deve ser na verdade conquistada.

${ }^{47}$ HEIDEGGER, 1999a, p. 115.

${ }^{48}$ HEIDEGGER, 1999a, p. 116.

${ }^{49}$ HEIDEGGER, 1993a, p. 23. O verbo Mitgehen significa ora "ir-com", ora "acompanhar".

${ }^{50}$ HEIDEGGER, 1993a, p. 263.

${ }^{51}$ HEIDEGGER, Anmerkungen zu Karl Jaspers, Psychologie der Weltanschauungen, in Wegmarken (GA 9), 1976, p. 34-35 (trad. bras.: Notas sobre "a psicologia das visões de mundo" de Karl Jaspers (1919/1921), 2008, p. 45-46.

${ }^{52}$ HEIDEGGER, 1999a, p. 117. 
(Welthaftigkeit) da vivência vivida" ${ }^{53}$. Em nome de um filosofar que brota imediatamente da vida supera-se assim a separação tradicional entre conceito e objeto defendida pela teoria do conhecimento do neokantismo. Se não existe primariamente uma posição de observador na vida vivida, só pode manifestar-se o viver com as coisas mesmas, as pessoas e a realidade na qual estou inserido. Antes de qualquer ato de concentração e relativização sobre essa vivência vivida, já estou sempre em relação com algo mundano mais amplo, sempre em um contexto de remissões: tudo é welthaft: mundano, com o sabor da mundanidade: "Vivendo em um mundo circundante, tudo para mim significa sempre e em todo lugar, tudo é mundano, munda [mundifica, se faz mundo] (es weltet)" ${ }^{\prime 54}$. Este célebre neologismo heideggeriano aparece no contexto da experiência de ver a cátedra do professor na sala de aula ${ }^{55}$ : primariamente, esta não se encontra $n a$ consciência, nem sequer como representação, mas a cátedra está no espaço acadêmico da aula universitária, junto à janela, diante do quadro, etc., pressupondo, portanto, uma ambientabilidade irredutível a coisas ou objetos com um determinado caráter de significado ao nível teórico: "na vivência de ver a cátedra alguma coisa me é dada ("gibt sich mir etwas") a partir do mundo circundante imediato". Esse "algo" é um elemento significativo primário da vivência imediata do mundo circundante: neste Erleben [o comportamento visual em direção à cátedra que se dá no mundo circundante], neste viver para [ou seja, em relação ao entorno], há algo de mim: meu eu sai completamente para fora de si mesmo e sintoniza (mitschwingt: literalmente "oscila", "vibra juntamente com) com este "ver'". O que se vê efetivamente? Vejo na verdade a "significatividade", por assim dizer ${ }^{56}$. O que se dá primariamente é, portanto, o "significativo", sem que se passe previamente pela sensação do tipo "percepção de uma cátedra", "sensação do marrom". Com esse exemplo de ver a cátedra afirma-se a primazia da significatividade sobre a coisidade na experiência vivida e, assim, Heidegger se posiciona contra o estatuto essencialmente epistemológico da subjetividade: o "eu" não é mais uma função primeira e espontânea - psíquica ou transcendental - apto para constituir sentido e conhecimento. Portanto, o "eu" advém na experiência vivida do mundo. Colocando-se radicalmente contra a intencionalidade de Husserl, Heidegger pensa já em 1919 que o mundo não poderia mais ser uma "função"

\footnotetext{
${ }^{53}$ HEIDEGGER, 1999a, p. 117.

${ }^{54}$ HEIDEGGER, 1999a, p. 73.

${ }^{55}$ No contexto dos primeiros cursos friburguenses, Heidegger rejeita as pressuposições teóricas de sujeito-objeto no interior da problemática da significação: cf. HEIDEGGER, 1999a, p. 72-73. Este schwingen torna-se schwimmen em GA 58. É o desmoronamento da supremacia do teorético: imerso em uma única melodia, "nado na corrente e deixo que as águas e as ondas rompam atrás de mim" [ ] "Vivo o nexo de significatividade. Este é gerado em meu ter experiência e através desse ter experiência como tal, na medida em que eu nado justamente nisso e naquilo em uma determinada direção de expectativas": HEIDEGGER, 1993a, p. 117. ${ }^{56}$ HEIDEGGER, 1999a, p. 72-73.
} 
correlativa de um ego transcendental: "o 'eu' só acontece na medida em que o mundo 'munda'". [...] "O 'eu' advém a ele mesmo simplesmente na vivência compreendida como evento apropriador (Er-eignis)" ${ }^{\prime \prime}$. Nesse Erbeben, enquanto vida vivida, onde se dá uma intimidade, um vibrar de eu-mundo-coisas-outros, em consonância, sem dualidades, tal como o compreende Heidegger em 1919, não é o estopim para o rompimento com a supremacia do teorético de seu mestre?

Se o esboço da fenomenologia hermenêutica se contrapõe à fenomenologia reflexiva de Husserl na medida em que este último interrompe a intenção primária da vida e da experiência com o escopo de objetivá-la teoreticamente, Heidegger determina no final do curso ( $A$ ideia da filosofia e o problema da vida de mundo) a "intuição hermenêutica" também como "formação originariamente fenomenológica que volta para trás por meio de retro-conceitos e que se antecipa mediante pré-conceitos (Rück- und-Vorgriffs-bildung) e da qual está excluída toda posição teorético-objetivante, transcendente ${ }^{\prime \prime 58}$. Anteriormente Heidegger utilizou os esses termos para expressar os caracteres fundamentais da vida como situação, motivação e tendência ${ }^{59}$ : "Rückgriff (motivação) e Vorgriff (tendência)" ${ }^{60}$. O sentido e a função da "intuição hermenêutica" não consiste na universalidade genérica (no sentido próprio do gênero) do conceito (Begriff), mas na dinâmica de uma "retomada" da vida pela sua tendência de perder a si mesma perdendo a experiência do mundo através do caminho teórico. Esta "retomada" se tornará particularmente importante quando Heidegger examinar posteriormente a total absorção do fático no mundo através, primeiramente, do fenômeno da "ruinância (Ruinanz)" e, em seguida, da "decaída (Verfallenheit)" ${ }^{61}$. A "concepção prévia (Vorgriff)" indica uma tendência de alcançar a vida em si e para si, sendo ao mesmo tempo uma "regressão (Rückgriff)" no motivo que deve ser pensado como eficaz no âmago do fático "Eu estou vivenciando alguma coisa".

A potencialidade de "alguma coisa" de originário expressa, antes de tudo, a vida como própria "em suas tendências motivadas e suas motivações tendenciais" ${ }^{62}$, ou seja, em sua mobilidade fundamental, o que corresponde

\footnotetext{
${ }^{57}$ ARRIEN, 2014, p. 72-73.

${ }^{58}$ HEIDEGGER, 1999a, p. 117.

${ }^{59}$ Cf. FISCHER, 2013, p. 180-183.

${ }^{60}$ HEIDEGGER, 1999a, p. 116.

${ }^{61}$ Cf. HEIDEGGER, Phänomenologische Interpretationen zu Aristoteles. Einführung in die phänomenologische Forschung (WS 1921/1922) (GA 61), 1985, (21994): “A ruinância pode ser determinada, portanto, em uma definição indicativo-formal: [trata-se da] mobilidade da vida fática que a vida fática executa - ou seja, 'é' (segundo um sentido de ser não ainda determinado) - nela mesma, enquanto ela mesma, para si mesma, a partir de si mesma para além de si mesma e em tudo isso contra si mesma" (131) (trad. bras.: Interpretações fenomenológicas sobre Aristóteles. Introdução à pesquisa fenomenológica, 2011, p. 147). Cf. também o comentário de ARRIEN, 2014, p. 333-336.

${ }^{62}$ HEIDEGGER, 1999a, p. 117.
} 
ao seu ser mesmo ${ }^{63}$. O verdadeiro sentido do vocábulo motivo não reside no fato de que a vivência, enquanto um pro-cesso (Vor-gang) que discorre em mim, em minha alma, seja algo evidentemente psíquico $^{64}$. Na concepção heideggeriana, entender motivos não significa "buscar causas do surgimento, condições de objetivação; tampouco significa buscar coisas que expliquem a vivência em termos de coisa e dentro de um contexto de coisas, isto é, colocando-a em um contexto material" 65 . Se "as vivências são eventos de a-propriação (Er-eignisse), enquanto vivem daquilo que lhes é próprio e é só assim que vive a vida", então só cabe ouvir, hermeneuticamente, "os motivos puros do sentido da vivência pura" ${ }^{\prime \prime 6}$. A pureza dos motivos do sentido (e das suas vivências) aponta para a pureza do fático no sentido da originariedade da vida pré-teórica, cujo esclarecimento se realiza com base na "recondução ao fenômeno da motivação"67. Esse retorno implica uma atitude fundamental de não objetivar reflexivamente as vivências cotidianas para nelas permanecer e, desse modo, extrair compreensivamente suas estruturas. Trata-se de entender as motivações hermeneuticamente com base na multiplicidade das situações inerentes à experiência da vida do eu histórico: “o eu-mesmo, o 'eu histórico' é uma função da 'experiência de vida" [...] "as situações se compenetram reciprocamente. O que se vive depende de motivos, os quais dependem, por sua vez, funcionalmente do passado. É só a coesão da vivência (Erlebniszusammenhang) que modela o eu histórico" ${ }^{\prime 68}$. Se a vida vivida é entendida como ritmo unitário que ressoa em múltiplas situações e, portanto, manifestando-se sempre como tensão, incerteza, insegurança, inquietude, então só cabe um critério fenomenológico: "a evidência que entende e o compreender evidente de vivências vividas (Erlebnissen), da vida em si e para si no eidos [entendido fenomenologicamente]" ${ }^{\prime 69}$.

Uma vez examinado globalmente o curso do semestre de pós-guerra de 1919, A ideia da filosofia e o problema da visão de mundo, vimos que Heidegger apropria-se produtivamente da fenomenologia de Husserl para acessar a vida em sua dimensão pré-teorética, e esta concepção hermenêutica da fenomenologia é aqui esboçada inicialmente como "ciência originária pré-teorética". Ainda que Heidegger reconheça o mérito de Husserl de ter insistido na significação principial da intuição, o conceito de "intuição fenomenológica" será considerado "insuficientemente originário". Acessar

\footnotetext{
${ }^{63}$ Cf. ARRIEN, 2014, p. 111.

${ }^{64} \mathrm{O}$ termo técnico Vor-gang indica o processo de objetivação teórica das vivências em Husserl. O eu teorético husserliano "se dissolve na vivência imediata e se transforma em um eu fático que sintoniza com o ritmo mesmo da vivência, que se deixa levar pela corrente significativa da vida mesma": ADRIAN ESCUDERO, 2010, p. 456.

${ }^{65}$ HEIDEGGER, 1999a, p. 66.

${ }^{66}$ HEIDEGGER, 1999a, p. 75.

${ }^{67}$ HEIDEGGER, 1999b, p. 121.

${ }^{68}$ HEIDEGGER, 1999c, p. 208-209.

${ }^{69}$ HEIDEGGER, 1999b, p. 126.
} 
a esfera primária da vida humana, isto é, o ser a-teórico de sua dimensão experiencial, antes de qualquer contemplação reflexiva, como é justamente o caso da "intuição objetivante" de Husserl, implica compreender suas estruturas transparentes sem violá-las nem objetivá-las. O compreender verdadeiramente fenomenológico já presente na expressão "intuição hermenêutica" pode ser comparado a um ser imerso na vida, ou seja, um ser em simpatia com a vida, o que concretamente indica a concepção hermenêutica da fenomenologia: "o primeiro estágio da investigação fenomenológica é o compreender" ${ }^{\prime \prime}$.

\section{Polêmica contra Husserl disfarçada de critica a Descartes: o "cuidado do conhecimento conhecido" 71}

O objetivo inicial do primeiro curso ministrado na Universidade de Marburg no semestre de inverno de 1923-1924 (Einführung in die phänomenologische Forschung $)^{72}$ era, primeiramente, definir os termos constitutivos da fenomenologia, isto é, phainómenon e logos, mediante um retorno a Aristóteles. Ao apropriar-se fenomenologicamente de Aristóteles nesse primeiro curso marburguense, Heidegger deixa claro que a filosofia grega se preocupa tanto com o ser do mundo quanto com o ser da vida na medida em que ela é sempre a vida dos entes intramundanos. Em segundo lugar, o exame dos textos aristotélicos constitui a plataforma sobre a qual Heidegger criticará a concepção fenomenológica de Husserl e, em seguida, sua apropriação de Descartes. A análise fenomenológica via Aristóteles é um esforço para compreender o porquê toda a história da filosofia (do Cristianismo em diante) ficou prisioneira de um pensar teorético e, portanto, distante da "inquietante estranheza" (Unheimlichkeit) da existência. O escamotear-se de nosso verdadeiro ser no pensar abstrativo sob a forma de asseguramento em relação à própria existência surge com a "predominância (Vorherrschaft) de uma ideia vazia e, portanto, fantástica, de certeza e evidência". Como entender que essa ideia de certeza, que se tornou "o cuidado por um determinado conhecimento absoluto", tenha conduzido a que "todo o

\footnotetext{
${ }^{70}$ HEIDEGGER, 1993a, p. 237-238.

${ }^{71}$ Cf. McGRATH, Heidegger. A (Very) Critical Introduction, 2008, p. 40: "a polemic with Husserl disguised as a critique of Descartes". Na prelação do semestre de inverno de 1923-1924 (GA 17), Heidegger polemiza contra a fenomenologia de Husserl e seu cartesianismo, uma vez que seu mestre "move-se plenamente no horizonte aberto por Descartes": HEIDEGGER, Einführung in die phänomenologische Forschung (WS 1923/1924) (GA 17), 1994, p. 254. Não se trata de identificar a doutrina de Husserl com a de Descartes, mas, para Heidegger, compreender autenticamente o que Husserl quer dizer implicaria examinar analogias intrínsecas entre as obras de ambos os filósofos. Sobre a GA 17, cf. INVERSO, Heidegger frente a Husserl en la Introducción a la investigación fenomenológica.", 2017, p. 49-72.

${ }^{72}$ HEIDEGGER, 1994 (trad. espanhola de Juan José García Norro, Introducción a la investigación fenomenológica, 2008).
} 
desenvolvimento da filosofia se subverta"73. Esta subversão se encontra no predomínio do "cuidado do conhecimento conhecido" (Sorge um erkannte Erkenntnis), que é uma curiosa expressão de Heidegger utilizada desde o verão de 1923. Esse cuidado "apareceu em uma virada da história da filosofia decisiva. Descartes é esta virada decisiva somente na medida em que nossa época se interpreta a si mesma e interpreta sua história sob a dominação do conhecimento teorético, ainda que Descartes, propriamente falando, seja completamente medieval"74. É justamente a crítica heideggeriana ao mecanismo explícito do uso husserliano de Descartes que pretendo explicitar aqui, sem, portanto, aprofundar a análise da fenomenologia via apropriação dos textos aristotélicos. Se a questão d na relação de Heidegger com Husserl no período friburguense (1919-1923) há ainda uma colaboração didática ao nível do synphilosophein e com base na célebre afirmação husserliana posterior ("A fenomenologia somos eu [Husserl] e Heidegger, de resto mais ninguém"75), mesmo no contexto de contínua tensão, o primeiro curso marburguense constitui certamente uma "polêmica contra Husserl disfarçada de crítica a Descartes" Justamente porque "Husserl se move plenamente no horizonte aberto por Descartes"77. Ainda que a relação de Husserl com Descartes seja bastante complexa, inegavelmente há uma dependência do filósofo francês, e esta dependência se descortina em dois pontos de convergência na abordagem husserliana de Descartes: o método cartesiano da dúvida como modelo originário da redução fenomenológica e o papel mitigado ou, ao menos, obscuro da intencionalidade em Descartes ${ }^{78}$. Compreende-se então porque "a fenomenologia é, por assim dizer, o anseio secreto de toda a filosofia moderna"79. Vejamos então a crítica de Heidegger a Husserl no espírito da "destruição" fenomenológica de retornar "às coisas mesmas". Mas aqui, diferentemente dos cursos de Freiburg e dos escritos que os precederam desde 1916, as preleções de Marburg (1923-1928) já se inserem na órbita de Ser e Tempo.

Uma vez que o confronto com a tradição filosófica realiza-se nesse curso (GA 17) com base em três grandes pilares da tradição filosófica - Tomas de Aquino, Descartes e Husserl -, o interesse fenomenológico consiste, portanto, em "retorno a Descartes e à ontologia escolástica que o determina" para que a própria fenomenologia se torne o que ela é chamada a

\footnotetext{
${ }^{73}$ HEIDEGGER, 1994, p. 43-44.

${ }^{74}$ HEIDEGGER, 1994, p. 128.

${ }^{75}$ GADAMER, O movimento fenomenológico, em Hegel - Husserl - Heidegger. Petrópolis: Vozes, 2012, 157-158.

${ }^{76}$ PERRIN, 2013, p. 94, nota 211.

${ }^{77}$ HEIDEGGER, 1994, p. 254.

${ }^{78}$ Cf. WELTEN, L'âme cartésienne de la phénoménologie, in Phénoménologie du Dieu invisible. Essais et études sur Emmanuel Levinas, Michel Henry et Jean-Luc Marion, 2011, p. 50-60.

${ }^{79}$ HUSSERL, Ideias I, § 62, p. 141.
} 
ser: um logos acerca do phainómenon. Como Husserl deixou-se seduzir por Descartes e, portanto, sem poder não pôde ser instruído por Aristóteles, o diagnóstico heideggeriano é inequívoco: as Logische Untersuchungen não souberam permanecer fieis nem à letra nem ao espírito "desses dois vocábulos [phainómenon e lógos] originários da filosofia grega". Nesse confronto direto com o mestre já se esboça o parentesco entre os dois conceitos para uma determinação autêntica da fenomenologia, tal como Heidegger estabelecerá em Ser e Tempo alguns anos mais tarde: o phainómenon que se entende como o que se mostra e o logos entendido como fazer ver. Esta infidelidade é marcada, segundo Heidegger, por vários pressupostos no pensamento husserliano: o ideal matemático como norma absoluta do pensar, a consciência como tema fundamental da investigação filosófica, a possibilidade e o estabelecimento de uma disciplina fundamental que garantam a unidade de todas as outras disciplinas do saber. Dentre esses pressupostos Heidegger destaca o critério de verdade da evidência que, sendo constitutivo para a compreensão da fenomenologia de Husserl, é determinado por "uma ideia vazia e ao mesmo tempo fantástica de certe$\mathrm{za}^{\prime \prime 8}$. Tal evidência é motivada pela preocupação husserliana por "determinado conhecimento absoluto" visto puramente como ideia que traz em si no campo de objetos assim estabelecido uma ciência da consciência. Os pressupostos mencionados podem ser reconduzidos ao "Sorge um erkannte Erkenntnis" (cuidado do conhecimento conhecido) ${ }^{81}$. Ele se preocupa com o "Sicherung der Erkenntnis auf dem Wege des Erkennens der Erkenntnis" (asseguramento do conhecimento no caminho do conhecer do conhecimento) ${ }^{82} \mathrm{e}$, com isso, tem em vista "Sicherung und Begründung einer absoluten Wissenschaftlichkeit" (asseguramento e justificação de uma absoluta cientificidade) ${ }^{83}$. Nesse sentido Heidegger reitera que esse "cuidado do conhecimento conhecido é fuga ante a existência como tal" ${ }^{84} \mathrm{em}$ suas dimensões de facticidade, que ameaça, estranhamento e cotidianidade. Trata-se de um cuidado, mas de um cuidado-preocupação com o conhecimento, que se explicita na atenção à consciência, promovida por Husserl como objeto da investigação filosófica na medida em que ela é a esfera ou a região de conjunto de vivências, conhecidas por nós através da "intuição interna"85. Se o "cuidado do conhecimento conhecido" que anima o ideal das ciências matemáticas é um "cuidado de certeza" ${ }^{86}$, e Husserl compartilha inegavelmente esse pressuposto de origem cartesiana, o pensamento husserliano seria uma forma de medo, de "angústia diante do Dasein" (Angst vor dem Dasein), de fuga face à insuperável insegurança (Unsicherheit) ${ }^{87}$ da "inquietante estranheza"

\footnotetext{
${ }^{80}$ HEIDEGGER, 1994, p. 43.

${ }^{81}$ HEIDEGGER, 1994, p. 61.100-103.

${ }^{82}$ HEIDEGGER, 1994, p. 72.

${ }^{83}$ HEIDEGGER, 1994, p. 72.

${ }^{84}$ HEIDEGGER, 1994, p. 112.

${ }^{85}$ HEIDEGGER, 1994, p. 54-55.

${ }^{86}$ HEIDEGGER, 1994, p. 221.

${ }^{87}$ HEIDEGGER, 1994, p. 57ss.97.
} 
(Unheimlichkeit) da existência ${ }^{88}$. Nesse A respeito desse cuidado pelo conhecimento conhecido, isto é, "pelo conhecimento justificado mediante o conhecimento mesmo", no qual em sua crítica a Husserl via o retorno a Descartes, Heidegger afirma: "a existência foge ante si mesma e renuncia à possibilidade de ver-se e compreender-se a si mesma de modo radical. Este é o sentido que tem o processo aparentemente inócuo de converter a consciência em campo temático" da fenomenologia ${ }^{89}$. Diante da facticidade do Dasein não há certeza: "Inquietante estranheza (Unheimlichkeit) é quando alguém pergunta o que ele é, nada, onde ele está, em lugar nenhum"90.

À base deste "cuidado do conhecimento conhecido" estão, segundo Heidegger, três pressupostos herdados em linha direta do cartesianismo: o homem de um tal cuidado deseja "a todo custo experimentar a verdade e preservá-la" $\left(1^{\circ}\right)$, "a verdade seria a validade" $\left(2^{\circ}\right)$, "a verdade e o ser da verdade se provam por uma dedução teorética" (3ำ $)^{91}$. Uma vez aceito o fato de que no pensamento de Husserl se constata uma preocupação - cuidado de asseguramento e fundação de uma cientificidade absoluta $^{92}-$, a fenomenologia fundada por ele no início do século XX está paradoxalmente mais próxima do cartesiano e da escolástica medieval tardia do que ao modo pensar próprio dos gregos que souberam articular os termos phainómenon e logos. Daí a necessidade de realizar uma "destruição" fenomenológica da "filosofia tradicional", da qual é visado, entre outros, sobretudo todo o cartesianismo. Mas é através da crítica a Descartes que Heidegger visa igualmente atingir Husserl. Os "preconceitos" atribuídos a Husserl por Heidegger bloqueiam "o acesso fenomenológico à pergunta do conhecimento humano como um modo específico da atuação fática da vida humana" ${ }^{\prime 93}$. Esse impedimento acontece justamente quando nesse "cuidado de certeza (Sorge der Gewissheit)" ${ }^{\prime \prime 4}$ há fundamentalmente uma preocupação para com a validez de proposições vinculativas; por essa razão, esse cuidado da validez assim determinado implica a transposição do ser mesmo e, portanto, o silêncio eloquente acerca de uma "duração temporal entre o nascimento e a morte". É justamente nessa "preocupação da certeza como preocupação da validez e da vinculatividade da proposição" que reside o interesse teorético na formação das ciências ${ }^{95}$. Portanto, o ente é assim entendido desde o início como "um determinado universo de regiões possíveis que pode ser alcançado por uma multiplicidade de ciências" ${ }^{\prime 96}$. Heidegger entrevê três repercussões existenciárias desse "cuidado do conhecimento conhecido",

\footnotetext{
${ }^{88}$ HEIDEGGER, 1994, p. 289-290.

${ }^{89}$ HEIDEGGER, 1994, p. 101.111.

${ }^{90}$ HEIDEGGER, 1994, p. 290.221.

${ }^{91}$ HEIDEGGER, 1994, p. 97.

${ }_{92}$ Cf. HEIDEGGER, 1994, p. 71ss.

${ }^{93}$ GANDER, 2004, p. 305.

${ }^{94}$ HEIDEGGER, 1994, p. 221.

${ }^{95}$ HEIDEGGER, 1994, p. 283.

${ }^{96}$ HEIDEGGER, 1994, p. 283.
} 
definido a partir de Husserl e, em seguida, reconduzido a Descartes. Em primeiro lugar, o "afastamento do ser (Seinsferne)" é não somente o conhecer, e não o ser, que é visado, mas é sobretudo o ser do conhecer que não é questionado; consequentemente, "o ser mesmo do conhecimento não tem transparência sobre as suas próprias possibilidades de $\operatorname{ser}^{\prime 98}$. A máxima da investigação fenomenológica - ir "às coisas mesmas" -, é uma promessa impossível de realizar, uma vez que Husserl parte de uma pré-compreensão tradicional da filosofia, a saber: a tradição proveniente de Descartes justamente com a sua problemática da razão. Face ao naturalismo e no contexto da exposição do elemento antipsicológico, deparamos com o ser da essência, com a preferência pelo racional, pelo conhecimento teorético e, consequentemente, pela ideia de uma cientificidade estrita e absoluta. À medida que se afirmar o cuidado de certeza, enquanto cuidado do conhecimento por si mesmo como mera representação das coisas, o Dasein permanecerá inteiramente escondido e escamoteado. Daí a segunda repercussão: a "ausência da temporalidade (Ausbleiben der Zeitlichkeit)" dado do conhecimento conhecido" persegue só o que é verdadeiro no sentido de que sua validade pode sempre ser verificada e jamais pode vacilar. Só se considera o que é, por assim dizer, sub specie aeternitatis. No contexto do liame fundamental do ser e do tempo pressentido por Heidegger nas origens da redação de seu opus Magnum entre 1923 e 1924, no final desse curso marburguense, ele afirma que "o cuidado da certeza é a dissimulação (Verstellen) do ser"100. Por fim, a terceira repercussão: o "nivelamento do ser (Einebnung des Seins)" da vida fático-histórica se encontra justamente na ideia da fenomenologia como ciência rigorosa de Husserl $^{101}$ : o cuidado da certeza inerente à ideia de fenomenologia está distante da descoberta autêntica da possibilidade de investigar em filosofia, a saber: uma fenomenologia arraigada em sua possibilidade mais própria da questionalidade: colocar a vida e suas realizações decisivas na mais radical problematicidade. Considerando que as coisas do mundo concreto evitam a investigação científica da existência (no sentido de que "não vemos as coisas como quididades isto é, como se fossem objetos de uma investigação científica"), "a existência das coisas [no mundo] é muito mais rica e oferece muitas mais possibilidades mutáveis do que as preparadas tematicamente [na ciência]"102. No contexto da subversão da investigação científica, "o cuidado da certeza obstrui (verbaut) [...] a possibilidade de que o ser do Dasein possa, antes dessa organização primária, ser encontrado de maneira ontológica em sua própria possibilidade". Nesse sentido

\footnotetext{
${ }^{97}$ HEIDEGGER, 1994, p. 281.

${ }^{98}$ HEIDEGGER, 1994, p. 286.

${ }^{99}$ HEIDEGGER, 1994, p. 282.

${ }^{100}$ HEIDEGGER, 1994, p. 283.

${ }^{101}$ HEIDEGGER, 1994, p. 283.

${ }^{102}$ HEIDEGGER, 1994, p. 37.
} 
toda a questão do ser é deslocada para a questão do ser-objeto (Gegenstandsein) para a ciência ${ }^{103}$. Com esse deslocamento teorético em Husserl para a consciência como campo temático da investigação fenomenológica, "não se chega mais a compreender a vida mesma em seu ser autêntico nem a responder à questão do caráter de ser"104. A "vida mesma em seu ser autêntico", permanecendo longe de todo movimento do cuidado da certeza, é exibida pela facticidade do Dasein e, mais explicitamente, pela facticidade do falar do Dasein: "A facticidade não é uma concreção do universal, mas a determinação originária de seu ser específico como Dasein"105. Facticidade é Dasein em seu aqui e agora, em sua cotidianidade e não em uma preocupação da certeza enquanto existência que se perde na reflexão teorética sobre si mesma. Uma genuína apropriação das coisas mesmas, enquanto objetivo da investigação fenomenológica, deve tomar como tema o Dasein fático: assim procedendo, Heidegger não tem em vista nenhum objeto em particular, nem tampouco qualquer região científica particular, mas somente "uma determinação que o caracteriza em seu como (Wie): o como se mostra a si mesmo e o como, fundado naquele outro como, se esconde"106. Quando o que está em jogo é o mostrar-se do Dasein no Como de seu próprio ser, e não a determinação do seu conteúdo como um ser da natureza ou uma realidade histórica, então "certeza e validade tornam-se impossíveis, porque o erro é uma dimensão essencial e inevitável do Dasein", dimensão esta revelada pela facticidade do falar (logos) do Dasein ${ }^{107}$.

A crítica heideggeriana a Husserl é reiterada em seu ataque constante nesse período à teorização da estrutura da intencionalidade. A preocupação da certeza na fenomenologia de Husserl, cuja inspiração deriva diretamente de Descartes, desfigura a intencionalidade "na medida em que, menos explícita que implicitamente, sempre a entende como específico comportamento teorético" ${ }^{\prime 108}$. Longe de compreender a intencionalidade voltada para o intencional no conhecer mesmo como se fosse uma propriedade de uma "região psíquica", Heidegger julga que o intencional jaz nos comportamentos da existência humana e, assim procedendo, rejeita sua localização nas vivências da consciência. No curso friburguense do semestre de inverno de 1921/1922 intitulado Interpretações fenomenológicas sobre Aristóteles (GA

\footnotetext{
${ }^{103}$ HEIDEGGER, 1994, p. 283.

${ }^{104}$ HEIDEGGER, 1994, p. 275.

${ }^{105}$ HEIDEGGER, 1994, p. 289. Nessa facticidade do falar (logos), que implica a inevitabilidade do erro, não obstante a pretensão da ciência de querer superá-lo, Heidegger aponta para o mundo concreto, onde se mostra a cotidianidade da existência: "Existe a possibilidade do erro só porque o mundo existe em sua riqueza, na concreção do viver em cada caso, fazendo assim muito mais extenso o seu caráter evasivo [isto é, do mundo]. Quanto mais concretamente estou no mundo, tanto mais própria é a existência do erro" (35).

106 HEIDEGGER, 1994, p. 45.

${ }_{107}$ CAMPBELL, 2012, p. 149.

${ }^{108}$ HEIDEGGER, 1994, p. 271.
} 
61) Heidegger perguntava-se sobre o que o inquietava há muito tempo: A intencionalidade terá caído do céu? No caso de que fosse um novíssimo, em que ultimidade (Letzheit) adotá-lo? Na verdade a convicção de Heidegger aqui jaz exatamente nisso: a intencionalidade é a estrutura formal fundamental de todas as estruturas categoriais da facticidade. Em vez de falar de atos psíquicos ou de uma suposta dualidade entre o ente psíquico e o ente físico, Heidegger preferirá descrever as formas de comportamento que mostram a vida em seu trato com o mundo, tais como o manipular, o dispor de, o produzir, o tratar com, o usar, o preocupar-se com, etc. O comportamento específico da vida é interpretado como cuidado (Sorge) em seus dois modos fundamentais: o ocupar-se (Besorgen) dos entes que comparecem no mundo circundante e a solicitude (Fürsorge) como modo próprio de tratar os outros. Assim, dentro da estrutura formal do cuidado, a intencionalidade adquire a forma positiva: com o comportamento ou o "'estar atrás de alguma coisa' de forma preocupada" (sorgendes[n] 'Aussein auf etwas' $)^{109}$ - onde o alguma coisa (Etwas) como aquilo-em-relação-a-quê (Worauf) do cuidado é o respectivo mundo fático-histórico - deparamos com a nova compreensão heideggeriana da intencionalidade como o pré-teórico "comportar-se-frente-a-algo (Sich-verhalten-zu-etwas) ${ }^{110}$. Se a relação real que emerge em todo conhecimento objetivo é o próprio cuidado, consequentemente o cuidado, em sua concepção teórica, nada mais é do que uma modificação possível do comportamento pré-teórico do homem que deve ser concebido como uma "mobilidade fundamental (Grundbewegtheit) própria ao Dasein" mais originária que a intencionalidade. Uma vez que o Dasein não é a consciência, cujo acesso se daria por uma "reflexão" teorética, mas fundamentalmente "mobilidade fundamental", não é possível, portanto, defini-lo como "um 'algo' que se refere a alguma coisa", um ego que se refere a um quid, ou a um aliquid"111. No "cuidado do conhecimento conhecido", o Dasein escamoteia a "inquietante estranheza" (Unheimlichkeit) da existência ${ }^{112}$, isto é, o Dass da vida fática. Essa indicação formal - Dass aponta para o puro "fato" da existência: a facticidade. A dinâmica interna da vida consiste no traço característico de "que ela é" (Dass-Charakter). Em um texto inaugural da época de Marburg (GA 62), Heidegger disse: "o caráter particular do 'que é' [eigentümliches Dass-Charakter] é acessível

\footnotetext{
${ }^{109}$ Cf. HEIDEGGER, Phänomenologische Interpretationen zu Aristoteles. Anzeige der hermeneutischen Situation., in: IDEM, 2005, p. 352. Com base no sentido literal da expressão técnica "Aussein auf etwas" ("ser, estar fora por", "atrás de alguma coisa"), sua significação é a seguinte: "estar à busca", "ir atrás de algo" ou "estar-ocupado-em-algo", "estar-voltado-para-algo", "manter-se-aberto-para-algo"): O Dasein está em busca de seu próprio ser no sentido de um "ser para ser (Sein-um), à busca de ser". Cf. também HEIDEGGER, 1975, § 31: “O cuidado enquanto ser do Dasein".

${ }^{110}$ HEIDEGGER, Interpretaciones fenomenológicas sobre Aristóteles. Indicación de la situación, 2002, p. 6-7. J. Escudero traduz assim: “No 'estar-ocupado-em-algo' (aus-sein-auf-etwas) está presente o horizonte (worauf) dentro do qual se move o cuidado da vida" (6).

${ }^{111}$ HEIDEGGER, 1994, p. 288.

112 Cf. PERRIN, 2013, p. 121-123. Cf. HEIDEGGER, 1994, p. 289.
} 
da maneira mais concreta a partir de seu nada [Nicht] específico, que nós chamamos a morte"113. Enquanto ameaça que nosso ser faz a si mesmo, esta "inquietante estranheza" tem sua expressão só na fuga diante de nós mesmos, na fuga, na familiaridade e no asseguramento veiculado pelo discurso do espaço público. O discurso teorético do das Man, tendendo para o Was de seu próprio interesse, constantemente se fecha em si mesmo e assegura-se em sua preocupação por um cuidado de conhecimento que encobre o Dass originário de nossa existência e, portanto, compreendendo a morte como contratendência em relação à auto-ocultação da vida em sua dimensão originária (Dass-Charakter). Uma vez que a familiaridade no mundo é aquilo para onde a fuga foge, então isso vem a significar o seguinte: "ante o que a existência foge no modo do cuidado da certeza, é o estranhamento. O estranhamento é autêntica ameaça sob a qual está o $D a$ sein. O estranhamento se mostra na cotidianidade do Dasein ${ }^{114}$. Essa relação cotidiana com a inquietante estranheza é traduzida por um "movimento de desvio que oculta ("abblende Abkehr) o não-ser-em-casa (Um-zuhause)" dando lugar assim ao ser-em-casa do ser-no-mundo familiar ${ }^{115}$. Com base em um contra-movimento existencial, Heidegger desoculta, isto é, arranca do esquecimento cotidiano a estranheza latente. O discurso fenomenológico de Heidegger reitera essa relação de fundação não-teorética ao voltar-se para aquela dimensão do Dass de nossa existência da qual o discurso cotidiano do espaço público se desgarra [das Man]: "O ser-no-mundo familiar e tranqüilizado é um modo do inquietante estranhamento do Dasein. $O$ não-ser-em-casa deve ser conceituado de modo ontológico-existenciário como o fenômeno mais originário"116. Esse fenômeno mais originário se exibe no discurso fenomenológico da angústia, a qual revela a insignificância, isto é, a inanidade e a "vaidade" do "mundo", cuja figura é destinada a passar: "na angústia, o utilizável do mundo-circundante se afunda, e em geral o ente intramundano. $\mathrm{O}$ 'mundo' já nada pode oferecer, nem também o Dasein-com (das Mitdasein) com os outros. A angústia priva assim o Dasein [humano] da possibilidade de compreender-se de maneira decadente a partir do 'mundo' e do público ser-do-interpretado"117.

No contexto da intensa confrontação com Descartes no curso do semestre de inverno de 1923/1924, Introdução à investigação fenomenológica, Heidegger rejeita o ideal de exatidão das matemáticas assumido pela fenomenologia de Husserl. Erigir as matemáticas como modelo (Vorbild) para toda ciência constitui um erro: "as matemáticas são a ciência menos rigorosa de todas, uma vez que o acesso nelas é muito mais fácil [...]. Esta imposição de um

\footnotetext{
113 Apud CIOCAN, La genèse du problème de la mort avant Être et Temps, 2011, p. 215-216.

${ }^{114}$ HEIDEGGER, 1994, p. 288-291.

${ }_{115}$ HEIDEGGER, Ser e Tempo, 2012b, § 40, p. 529-531, (SZ [= Sein und Zeit], p. 189).

${ }_{116}$ HEIDEGGER, 2012b, § 40, p. 531 (SZ, p. 189).

117 HEIDEGGER, 2012b, § 40, p. 525 (SZ, p. 187).
} 
modelo é antifenomenológico"118. Ora, tal declaração equivale à condenação da paixão de Husserl pela mathesis universalis, esta ciência admirável da ordem e da medida sonhada por Descartes, paixão que se transformou na intuição como a intenção liminar da fenomenologia husserliana. Todavia, o modo de pensar segundo a evidência das matemáticas impede um acesso genuinamente fenomenológico às coisas mesmas, uma vez que as distorce a partir da perspectiva da subjetividade reflexiva. $O$ critério de evidência presente em Husserl está determinado pelo predomínio de "uma ideia vazia e ao mesmo tempo fantástica de certeza"119. Com base no critério de cientificidade assim imposto, as coisas mesmas não se mostram em si mesmas, como exige o lema fenomenológico. Heidegger assume criticamente o pensamento de Husserl, sobretudo o pressuposto da "evidência fenomenológica" e, aplicando-o contra o próprio Husserl, distingue entre atitude fenomenológica e teorética. A primazia dada ao teorético distorce o nosso acesso ao mundo da vida à medida que desvitaliza o âmbito primário das vivências imediatas diante do "observar" coisificador do sujeito. Uma vez que o conhecimento filosófico se identifica com conhecimento científico em Husserl, o mesmo carece da radicalidade na interpretação da reflexão fenomenológica. Daí a passagem da consciência reflexiva husserliana, cuja preocupação consiste principalmente em depreender uma região - a região consciência como esfera absoluta das vivências ${ }^{120}$ - à "situação hermenêutica" em Heidegger, e essa "situação hermenêutica" vem a ser um "compreender" fenomenológico imerso na própria vida fática, uma "imersão na coisa" mesma (Hingabe an die Sache) sem contaminação com qualquer tipo de teoremas ou concepções prévias ${ }^{121}$. Trata-se de um simpatizar com a realidade mesma da "vida em si e para si". Na intuição originária, na correspondência pré-teórica, a vida se tem, se atua (e, portanto, não se conhece sob o modo de objeto em seu ter conhecimento): "sem preocupar-se com a objetivação teórica alguma", a vida "se tem de modo vivo e neste ter se realiza"122. Portanto, "com a apropriação da situação hermenêutica ganha-se o horizonte prévio no qual se move sempre a vida"123, e esta situação hermenêutica possui três momentos estruturais: o

\footnotetext{
${ }^{118}$ HEIDEGGER, 2012a, p. 79-80.

${ }^{119}$ HEIDEGGER, 1994, p. 43.

${ }^{120}$ Cf. QUESNE, 2003, p. 141.

${ }^{121}$ HEIDEGGER, 1999a, p. 61.

${ }^{122}$ HEIDEGGER, 1993a, p. 156.

${ }^{123}$ ADRIAN ESCUDERO, 2016, p. 138.105. Com base nos cursos do jovem Heidegger, trata-se, por assim dizer, de tornar o presente passado no sentido do abrir-se de uma situação a partir do presente da intuição, a qual possui sempre uma espessura, um relevo: "... Segue o ver prévio (Vorschauen), o saltar prévio (Vorausspringen) da intuição fenomenológica aos horizontes que estão dados na experiência da vida mesma, às tendências e aos motivos que há na experiência da vida": HEIDEGGER, 1993a, p. 254-255. Sobre a relação entre o sentido quotidiano de Vor- e o sentido filosófico dos termos fundamentais, cf. HEIDEGGER, 1993a, p. 186: "No recordar, o viver vive em uma articulação de si-mesmo, que implica um distanciamento com ele mesmo". A propósito, cf. QUESNE, 2003, p. 132: “O Vor- como tal é o passado nesse sentido de que o passado pode ser perda completa dos objetos e das
} 
ter-prévio (Vorhabe), o ver-prévio (Vorsich) e a concepção prévia (Vorgriff) ${ }^{124}$. O Vorhabe da investigação mesma é o Dasein; o segundo concerne ao "ser", ou seja, ao Dasein "segundo as possibilidades e segundo os modos de seu ser"; o último é determinado pelo fato de ser "explicitados os caracteres de ser"125. Por fim, em termos de Ser e Tempo, em cujo horizonte já se insere esse primeiro curso de Marburg (Introdução à investigação fenomenológica de 1923/1924), concluamos: nosso contato primário com o mundo se coloca na pré-compreensão que o Dasein já sempre possui de seu ser: o Dasein é o ente "onticamente assinalado, pois para esse ente está em jogo em seu ser esse ser ele mesmo" e que "a compreensão do ser (Seinsverständnis) é ela mesma uma determinidade do ser (Seinsbestimmtheit) do Dasein"126. Se o Dasein é assim um ente privilegiado, que existe e compreende de algum modo seu ser, "ainda que não conceituado de modo ontologicamente adequado"127, a existência é um modo de ser, ou seja, um modo de ser próprio do Dasein. Portanto, toda interpretação do Dasein já se move sobre o solo de algo já dado. O ser que se tornou acessível à compreensão não pode ser mais "objetivado", como aconteceu na tradição com o primado da intuição e do objeto da intuição. Então o desafio da ontologia fundamental consistiria desse modo em "substituir a intuição objetivante pela compreensão não-objetivante", o que equivaleria "à transformação da fenomenologia transcendental-eidética de Husserl na fenomenologia hermenêutica de Heidegger"128.

\section{Referências}

\section{Obras de Martin Heidegger (GA = Gesamtausgabe)}

M. HEIDEGGER, Die Kategorien- und Bedeutungslehre des Duns Scotus.Tübingen: J.C.B. Mohr,1916. Publicação retomada in: Frühe Schriften (1912-1916) (GA 1).Frankfurt am Main: Vittorio Klostermann, 1978 .

Die Idee der Philosophie und das Weltanschauungsproblem (Kriegsnotsemester1919), In: Zur Bestimmung der Philosophie (GA56/57). Frankfurt am Main: Vittorio Klostermann, 1999a, pp. 1-117.

coisas, mas conservação de uma situação de sentido distinto, que ela seja dada em uma interpretação já elaborada ou em um sentimento difuso da situação".

${ }^{124}$ Sobre esses três momentos da pré-estrutura da compreensão, ver o comentário do $\S 32$ de Ser e Tempo em ADRIAN ESCUDERO, 2016, p. 275-282.

${ }^{125}$ HEIDEGGER, 1994, p. 109-110.

${ }^{126}$ HEIDEGGER, 2012b, § 4, p. 59 (SZ, p. 12).

${ }^{127}$ HEIDEGGER, 2012b, § 42, p. 557 (SZ, p. 200).

${ }^{128}$ T. KISIEL, 1995, p. 376.368.373. 
Phänomenologie und transzendentale Wertphilosophie [SS 1919]. In: Zur Bestimmung der Philosophie (GA 56/57). Frankfurt am Main: Vittorio Klostermann, 1999b, pp. 121-203.

Über das Wesen der Universität und des akademischen Studiums [SS 1919]. In: Zur Bestimmung der Philosophie (GA 56/57). Frankfurt am Main: Vittorio Klostermann, 1999c, pp. 205-214.

Anmerkungen zu Karl Jaspers, Psychologie der Weltanschauungen (1919-1921). Publicado originalmente in: SANER, H. (Hrgs.), Karl Jaspers in der Diskussion. München: Piper, 1973, pp. 70-100. Publicação retomada In: Wegmarken (GA 9). Frankfurt am Main: Vittorio Klostermann, 1976, pp. 1-44 (trad. bras.: Notas sobre "a psicologia das visões de mundo" de Karl Jaspers (1919/1921). In: Marcas do caminho.Petrópolis: Vozes, 2008).

Grundprobleme der Phänomenologie [WS 1919/20] (GA 58). Frankfurt am Main: Vittorio Klostermann, 1993a, (2010).

Phänomenologie der Anschauung und des Ausdrucks. Theorie der philosophischen Begriffsbildung [SS 1920] (GA 59). Frankfurt am Main:Vittorio Klostermann, 1993b (2007) (trad. it. a cura de Vincenzo Costa: Fenomenologia dell'intuizione e dell'espressione. Macerata: Quodlibet,2012).

Einleitung in die Phänomenologie der Religion. In: Phänomenologie des religiösen Lebens [WS 1920/1921] (GA 60). Frankfurt am Main: Vittorio Klostermann, 1995 (22011), pp. 1-156.

Phänomenologische Interpretationen zu Aristoteles. Einführung in die phänomenologische Forschung [WS 1921/1922] (GA 61). Frankfurt am Main: Vittorio Klostermann, 1985, ( $\left.{ }^{2} 1994\right)$

Phänomenologische Interpretationen zu Aristoteles. Anzeige der hermeneutischen Situation. In: Phänomenologische Interpretationen ausgewählter Abhandlungen des Aristoteles zu Ontologie und Logik. [SS 1922] (GA 62), 2005, Anhang III p.343-420. Publicado originalmente in: Dilthey-Jahrbuch 6 (1989), pp. 236-274 (trad. espanhola: Interpretaciones fenomenológicas sobre Aristóteles. Indicación de la situación hermenéutica [Informe Natorp]. Edición y tradución de Jesús Adrián Escudero. Madrid: Editorial Trotta, 2002).

Ontologie. (Hermeneutik der Faktizität) [SS 1923] (GA 63). Frankfurt am Main: Vittorio Klostermann, 1988, (trad. bras.: Ontologia (Hermenêutica da facticidade). Petrópolis: Vozes, 2012a).

Einführung in die phänomenologische Forschung [WS 1923/1924] (GA 17). Frankfurt am Main: Vittorio Klostermann, 1994 (2006) (trad. espanhola de Juan José García Norro, Introducción a la investigación fenomenológica. Madrid: Síntesis, 2008).

Prolegomena zur Geschichte des Zeitbegriffes [SS 1925] (GA 20). Frankfurt am Main: Vittorio Klostermann, 1975.

Sein und Zeit (GA 2). Frankfurt am Main: Vittorio Klostermann, 1977 (Hrsg. Friedrich-Wilhelm von Hermann). Utilizo a seguinte tradução brasileira: 
edição em alemão e português. Trad., organização, nota prévia, anexos e notas por Fausto Castilho. São Paulo-Petrópolis: Editora Unicamp-Vozes, 2012b.

Kant und das Problem der Metaphysik [1929] (GA 3). Frankfurt am

Main: Vittorio Klostermann, ${ }^{5} 1991$.

\section{Correspondência de Heidegger}

HEIDEGGER, M., Briefe Martin Heideggers an Engelbert Krebs (1914-1919). In: DENKER, A.; GANDER, H.-H.\& ZABOROWSKI, H. (Hrsg.), Heidegger und die Anfünge seines Denkens. Heidegger-Jahrbuch 1. München: Verlag Karl Alber, 2004, pp. 67-68.

\& JASPERS, K., Correspondencia (1920-1963). Madrid: Síntesis, 2003 (original alemão: Briefwechsel 1920-1963. München- Frankfurt am Main: PiperVittorio Klostermann,1990).

Alma mia! Cartas a su mujer Elfride 1915-1970. Buenos Aires: Manatial, 2008 (original alemão: Mein liebes Seelchen! Briefe Martin Heideggers an seine Frau Elfride. München [ed. Gertrud Heidegger]: Deutsche Verlags-Anstalt, 2005).

\section{Outras fontes}

ADRIAN ESCUDERO, J. Heidegger y la genealogía de la pregunta por el ser. Una articulación temática y metodológica de su obra temprana. Barcelona: Herder, 2010.

celona: Herder, 2016.

Guía de lectura de Ser y Tiempo de Martin Heidegger. Vol 1. Bar-

ARRIEN, S.-J. L'inquiétude de la pensée. L'herméneutique de la vie du jeune Heidegger (1919-1923). Paris: PUF, 2014.

BANCALARI, S. L'altro e l'esserci. Il problema del Mitsein nel pensiero di Heidegger. Padova: CEDAM, 1999.

BRAVER, L. Analyzing Heidegger: a history of analytic reactions to Heidegger. In: DAHLSTROM, D.O. (ed.), Interpreting Heidegger. Critical Essays. Cambridge: Cambridge University Press, 2015, pp. 235-255.

CAMPBELL, S.M. The Early Heidegger's Philosophy of Life. Facticity, Being, and Language. New York: Fordham University Press, 2012.

CAPUTO, A. Pensiero e affettività: Heidegger e le Stimmungen (1889-1928). Milano: Franco Angeli, 2001.

CIOCAN, C. La genèse du problème de la mort avant Être et Temps. In: S.-J. ARRIEN \& S. CAMILLERI, (éd.), Le jeune Heidegger 1909-1926. Paris: J. Vrin, 2011, pp. 213-237.

CRISTIN, R. Husserl-Heidegger: la fenomenologia in discussione. In: HUSSERL, E. \& HEIDEGGER, M., Fenomenologia. Milano: Unicopoli, 1999, pp. 11-129. 
DENKER, A. Heideggers Lebens- und Denkweg 1909-1919. In: DENKER, A.; GANDER, H.-H.\& ZABOROWSKI, H. (Hrsg.), Heidegger und die Anfünge seines Denkens. Heidegger-Jahrbuch 1. München: Verlag Karl Alber, 2004, pp. 97-122.

ESCUDERO PÉREZ, E. Husserl y Heidegger en 1927. In: Ápeiron. Estudios de filosofia - Filosofia y Fenomenologia, v. 3, 2015, pp.61-82.

FISCHER,M. Religiöse Erfahrung in der Phänomenologie des frühen Heidegger. Göttingen : Vandenhoeck \& Ruprecht, 2013.

GADAMER, H.-G. O movimento fenomenológico (1963). In: Hegel - Husserl - Heidegger. Petrópolis: Vozes, 2012, pp. 143-199.

GANDER, H.-H. Phänomenologie im Übergang. Zu Heideggers Auseinandersetzung mit Husserl. In: DENKER, A.; GANDER, H.-H. \& ZABOROWSKI, H. (Hrsg.), Heidegger und die Anfänge seines Denkens. Heidegger-Jahrbuch 1.München: Verlag Karl Alber, 2004, pp. 294-306.

Phänomenologie der Lebenswelt: Husserl und Heidegger, In: FIGAL, G. \& GANDER, H.-H (Hrsg. von), Heidegger und Husserl. Neue Perspektiven. Frankfurt am Main: Vittorio Klostermann, ${ }^{2} 2013$, pp. 137-158.

GREISCH, J. L'Arbre de vie et l'arbre du savoir. Les racines phénoménologiques de l’herméneutique heideggerienne (1919-1923). Paris: Cerf, 2000.

HUSSERL, E. Ideias para uma fenomenologia pura e para uma filosofia fenomenológica. Livro Primeiro. Aparecida [SP]: Ideias \& Letras, 2006.

JACOBSSON, M. Heidegger e Dilthey.Vita, morte e Storia. Milano: Mimesis Edizioni, 2010.

KOVACS, G. Philosophy as Primordial Science in Heidegger's Courses of 1919, In: T. KISIEL \& J. VAN BUREN (ed.), Reading Heidegger from Start. Essays in his Earlier Thought. New York: SUNY Press, 1994, pp. 91-107.

KISIEL, T. The Genesis of Heidegger's "Being and Time". Berkeley/Los Angeles/London: University California Press, 1995.

PERRIN, Ch. Entendre la métaphysique. Les significations de la pensée de Descartes dans l'oeuvre de Heidegger. Louvain-Paris: Peeters, 2013.

QUESNE, Ph. Les recherches philosophiques du jeune Heidegger. Dordrecht: Kluwer Academic Publishers, 2003.

RESE, F. (Hrsg. Von1). Heidegger und Husserl im Vergleich. Frankfurt am Main: Vittorio Klostermann, 2010.

WESTERLUND, F. Phenomenology as Understanding of Origin. Remarks on Heidegger's First Critique of Husserl. In: RESE, F. (Hrsg.). Heidegger und Husserl im Vergleich, 2010, pp. 34-56.

SCHMIDT, I. La vie comme défi phénoménologique. La pensée du jeune Heidegger comme critique de la science rigoureuse. In: S.-J. ARRIEN \& S. CAMILLERI (éd.). Le jeune Heidegger 1909-1926. Paris: J. Vrin, 2011, pp. 119-133. 
WELTEN, R. L'âme cartésienne de la phénoménologie. In: Phénoménologie du Dieu invisible. Essais et études sur Emmanuel Levinas, Michel Henry et Jean-Luc Marion. Paris: L'Harmattan, 2011, pp. 49-80.

XOLOCOTZI, A. \& TAMAYO, L. Los demonios de Heidegger. Eros y manía en el maestro de la Selva Negra. Madrid: Editorial Trotta, 2012.

ZAHAVI, D. Comment examiner la subjectivité? À propos de la réflexion: Natorp et Heidegger. In: ARRIEN, S.-J \& CAMILLERI, S. (éd.), Le jeune Heidegger 1909-1926. Paris: J. Vrin, 2011, pp.103-104.

Endereço do Autor:

Programa de Pós-Graduação em Filosofia

Centro de Ciências Humanas e Naturais (CCHN)

Av. Fernando Ferrari, 514

Campus Universitário Alaor Queiroz Araújo - Goiabeiras

29076-910 Vitória - ES

benedictus1983@gmail.com 